\title{
ニューラルネットワークを用いた変化球制御型 ピッチングマシンの開発*
}

\author{
尾田十八*1, 酒井忍*1, 米村茂*2 \\ 河田憲 吾*3, 堀川三 郎*4, 山本 博 之*4
}

\section{Development Research of Pitching Machine Controlling Variable Ball using Neural Network}

\author{
Juhachi ODA ${ }^{* 5}$, Shinobu SAKAI, Shigeru YONEMURA, \\ Kengo KAWATA, Saburo HORIKAWA and Hiroyuki YAMAMOTO \\ ${ }^{* 5}$ Department of Human \& Mechanical Systems Engineering, Kanazawa University, \\ 2-40-20 Kodatsuno, Kanazawa-shi, Ishikawa, 920-8667 Japan
}

\begin{abstract}
The most common commercial pitching machines are the "two rollers" type and also the "arm" type. These machines tend to have certain limitations. In particular it is very difficult to simultaneously change both ball speed and direction. Also some types of pitches, such as the curve or sinking ball, are not easily achieved. In this study, the hardware and software design of a new "intelligent" pitching machine which is able to pitch repeatably with selectable speed, direction and ball rotation, is presented. The machine had three rollers and the motion of each was independantly controlled by a heirarchical neural network. This network accepted ball speed, direction and rotation as inputs and produced detailed motion control of the three rollers as output.
\end{abstract}

Key Words : Pitching Machine, Base Ball, Neural Network, Intelligent Machine, Learning

\section{1. 緒 言}

ピッチングマシンは野球のバッティング練習の際に 投手の代わりに投球を行うマシンであり, プロ野球か らバッティングセンターまで幅広く利用されている. ピッチングマシンの一番の目的は, 攻略したい相手投 手のピッチングを再現し, バッティング技術を向上さ せることである. 既存のピッチングマシンを用いれば ハイスピードボールや変化球も投球することは可能で ある. しかしながら, 従来使用されているアーム式ま たは，2 ローラ式のピッチングマシンでは投球の速度 とコースを同時かつ即座に変更することは困難である. さらに任意の球種（カーブ, シュート等）いわゆる変 化球を希望するコースおよび速度に投げ分けることは ほとんど不可能に近い.

\footnotetext{
* 原稿受付 2004 年 5 月 28 日.

*1 正員, 金沢大学工学部 ( 920-8667 金沢市小立野 2-40-20).

*2 学生員, 金沢大学大学院自然科学研究料.

*3 金沢大学大学院自然科学研究料.

*4 (株)キンキクレスコ( 563-0025 池田市城南 3-3-12).

E-mail : oda18@t.kanazawa-u.ac.jp
}

そこで本研究では 3 個のローラを用いそのローラの 回転数を各々独立に制御すると同時に, ボールの発射 角を制御することによって, 従来不可能であった任意 の球種のボールを希望するコース, 速度に投げ分ける ことのできる新型のピッチングマシンの製作を試みた. これは著者らがすでにコースと速度のみを可変できる ものとして開発してきたピッチングマシン(1)をさらに レベルアップしたもので, その制御法にはニューラル ネットワーク（以下 NN）を用いている.この NNでは 各コース, 速度, 球種を入力データ, 各ローラの回転 数および上下, 左右の発射角を出力データとして学習 を行い, バッターが希望するピッチングが可能となる ようにしている. ここではそのようなピッチングマシ ンのシステムとその性能評価について記述する.

\section{2.ピッチングマシンの現状とその問題点}

ピッチングマシンにとって重要な性能の一つは, 所定 のスピードを発揮できる能力を有することである. それ には，現在市販されているような人間の腕を模倣してボ 
一ルを投球する機構で, ばねとクランクを応用したアー ム式（図1）と，ローラを2個用いそれらを回転させ，口 一ラとボールとの摩擦力を利用してボールを発射させる 2ローラ式 (図2)の2つがある. 一般にアーム式の場合 は速度のみ可変できるが, コースの変更は不可能である. また 2 ローラ式ではボールに与えられる回転の方向は口 一ラが回転する平面上でしか与えられないのでボールは その平面上にしか飛儿で行かない，つまりその平面上で は回転数を変えることによって変化球やスピードを変え ることが可能であるが，任意の変化球を得るためには， その平面を手動で回転させ，また試行錯誤的に回転軸を 決定しているのが現状である.このように，既存のピッ チングマシンは機構的にはある程度完成されたものとな っているが以上述ベた欠点があるため，バッターが希望 する球種やスピードのボールを任意のコースに投げ分け ることが不可能である.

そこで著者らは以上述べたような既存のピッチングマ シンに不足していると考兄ら机る基本的な機能，すなわ ちバッターが希望する球種 (変化球) およびスピードの ボールを希望するコースに自在に投げ分けることが可能 な構造をもつピッチングマシンを開発することにした。 そしてさらにそのマシンか使用される環境に対して適応 して進化していくようなマシンを考えた．例えば風速， 地面の傾き，気温，ボールの種類などか湾化した状況下 でも何球か試球をすればその環境における適性を学習し てマシン自身の特性を変化させ, 求めるコースや速度の 投球を行うようなものである. このようなマシンを著者 らは知的ピッチングマシンと呼んでいる.

\section{3. 新型ピッチングマシンとその構造}

さて，著者らはコースと速度の 2 つのパラメータを任 意に制御し得る知的なピッチングマシンをすでに開発し ている(の。これ忧ールの発射位置周りに3個のローラ を配置したもので，各ローラの回転数を様々に変えるこ とによってボールの回転方向は，3個のローラの回転軸 を結ぶ平面に対して垂直に 360 度とることが可能である.

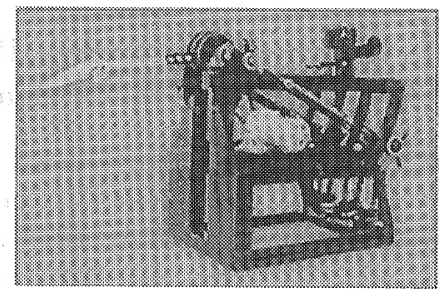

Fig.1 Pitching machine (arm type)

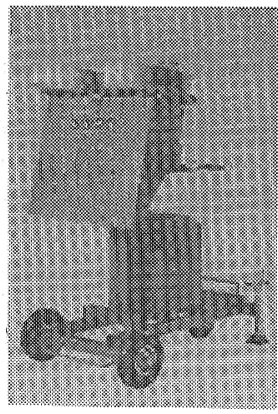

Fig.2 Pitching machine ( 2 rollers type)

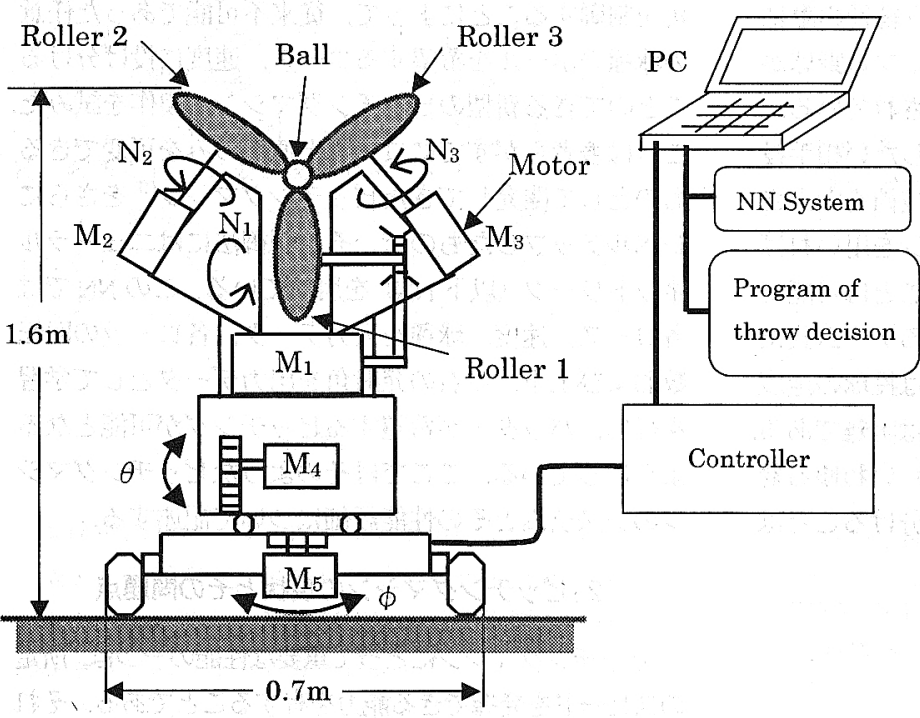

Fig.3 Constitution of the new pitching machine

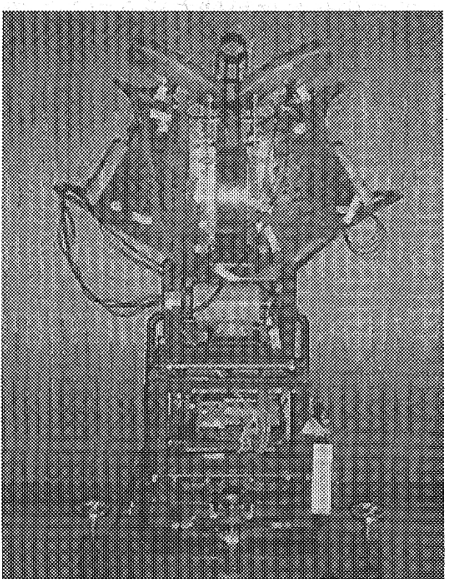

Fig.4 New pitching machine (3 rollers type) 
よってこの構造であれば 3 次元空間内の様々な球速，コ 一スのみならず種々の球種の投球も可能であると考えら れる. ただ前開発マシンでは, コースと球速制御のみに 注目したが，この分野の二ーズを調査したところ球速と 球種の選定が特に重要であり,コースの選定はこれらに 次ぐものであることが明らかとなった(2)。そこで, 本報 では, 球速，球種，コースの3つを制御し得る新しい知 的ピッチングマシンを開発することにした.

製作した新型のピッチングマシンの構造およで制御シ ステムを図3に，またその写真を図 4 に示す. 図3から 分かるように, ボールは発射位置周りに 120 度間隔で Y 字型に設置された 3 個のゴム製のローラとの摩擦力を利 用して発射される. 各ローラにはそれぞれモ一タが設置 されておりVベルトを介して連動し，回転数は０～2300 pm まで可変でき各モ一夕は各々独立に制御される.さらに これらのボールを任意のコースに投げ分けるため, マシ ン下部にモータ $\mathrm{M}_{4}$ および $\mathrm{M}_{5}$ を設置し，マシン本体の上 下角 $\theta$ を $6 \sim+6^{\circ}$, 左右角 $\phi$ を $5 \sim+5^{\circ}$ まで可变できる ようにした.これらの新機構を採用した新型ピッチング マシンでは, 最高速 $160 \mathrm{kmh}$ まで任意の球速で, かつ 広範囲の希望するコースに, 任意の球種のボールを投球 することが可能である.

なお, 各モータはコントローラを介してPCに接続され おり，PC上でモ一夕の回転数を制御可能にしている. ま た, 各種センサを用いて3個のローラの回転数 $N_{1}, N_{2}, N_{3}$, マシンの上下角 $\theta$, マシンの左右角 $\phi$, ボールの初速度 Vを実測している.

\section{NNを用いた投球制御方法について}

3 章で説明した多機能な知的ピッチングマシンの制御 には, 階層型 NNを用いている. 次にその制御方法につ いて述べる. 本制御では, 基本的に投球したいボールの コース座標 $X, Y$, 速度 $V$ おど後述する球種パラメータ
$B_{X} ， B_{Y}$ の 5 つの入力情報から，そのような投球をするた めの各ローラの回転数 $N_{\mathrm{b}} N_{2}, N_{3}$ とマシンの上下角 $\theta$, 左 右角 $\phi の ~ 5$ 変数を出力情報とするシステ云を構策すれば よい.そ㧈には理論的にボールの飛翔方向を算出する方 法(3)がまず考えられる. そして, その手法については, 著者らはすでに前報(1)で述べているようにボールの抗力 係数やマグナスカ等を測定することで一応可能ではある が,これらには非常に手間と時間を要し，かつその割に 精度の良いものとはならない。

そこで, 複雑な理論式を用いなくとも入出力間関係を

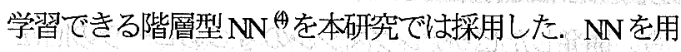
いれば、いくつかの教師データを与えることによつてNN 自体が学習し，正しい出力をするようになる. ゆえに本 マシンのようにマシン自体の特性が，その置かれた環境 や使用法等に影響されるような非常に複雑な事象の制御 問題に対して,NNは有効な手段である. そこで本研究で 用いた階層型 NNは，図 5 に示すような入力情報として ボールのコース座標 $X, Y$, 速度 Vおよひ球種パラメータ $B_{X}, B_{Y}$ の 5つを, 一方 3 個の口-ラの回転数 $N_{1}, N_{2}, N_{3}$ と マシンの上下角 $\theta$ および左右角 $\phi$ の 变数を出力情報と する3層のネットワークしした.

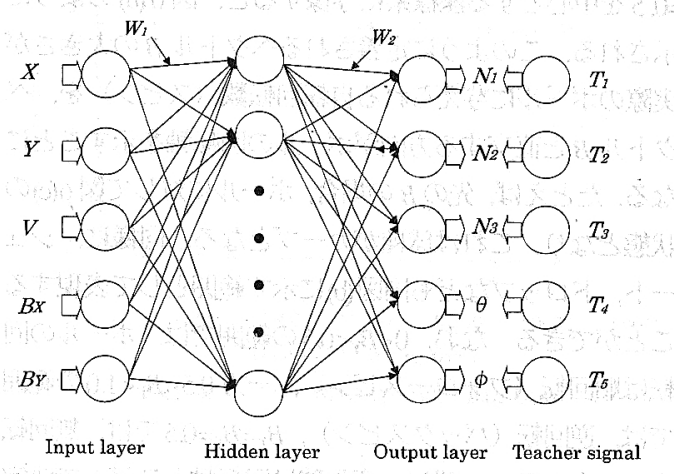

Fig.5 Neural network model

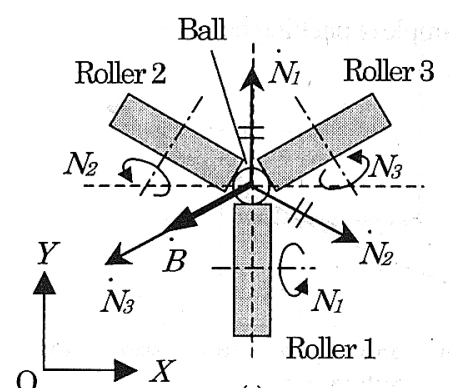

(a)

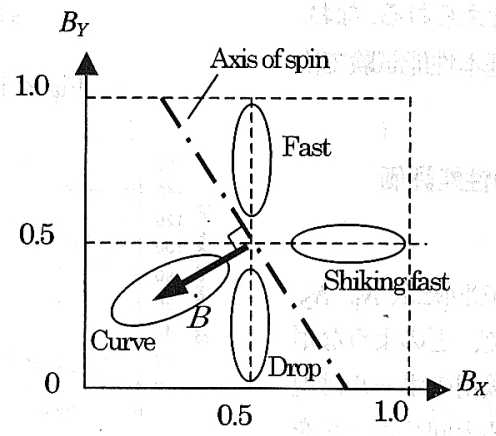

(b)

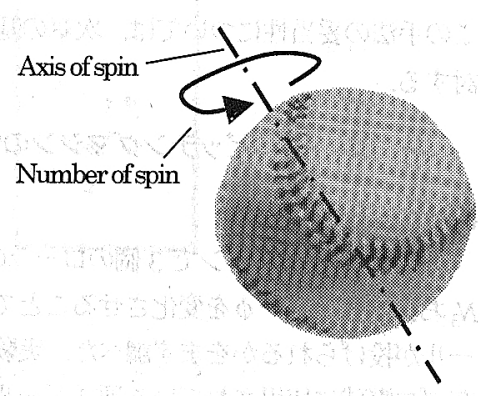

(c)

Fig.6 Variable ball parameter : $B_{X}, B_{Y}$ 
この NNに教師データ $T_{i}$ を与え, 出力 $N_{i}$ と教師データ との差の 2 乗, すなわち 2 乗誤差 : $\left(T_{i}-N_{i}\right)^{2} / 2$ をバック プロパゲーション法（誤差逆伝播法）によって隇少させ て行くことによって学習し, 正確な出力をするような NN を構築した.

\section{5. 球種パラメータ $B_{X}, B_{Y}$}

さて, カーブやシュートなどの変化球を本報では球種 と呼んでいるが, これを球種パラメータ $B_{X}, B_{Y}$ のつで 表現する手法を提案する.

今, 開発したピッチングマシンの 3 つのローラの回転 数 $N_{1}, N_{2} N_{3}$ を変化させ, $N_{3}>N_{1}=N_{2}$ の関係にあるとする. このとき, 各ローラがボールに与える回転モーメントを ベクトルで表現すると, 各ローラに対応したべクトル $\dot{N}_{1}$, $\dot{N}_{2}, \dot{N}_{3}$ はそれぞれ120度間隔なので図6(a)で示される. ま たこの場合, $N_{3}$ による回転べクトル $\dot{N}_{3}$ の大きさが最も大 きく, $N_{1}, N_{2}$ による回転べクトル $\dot{N}_{1}, N_{2}$ の大きさは互い に等しいものとなる.これら 3 つのベクトルを合成する と, 図中の $\dot{B}$ となる. このベクトルの大きさをローラの 最大回転数で無次元化し横軸が $B_{X}$, 縦軸が $B_{Y}$ で, $B_{X}=B_{Y}$ $=0.5$ を中心とする座標系に写像すると, 図 6(b) のように 示される. このように定義されるべクトル $\dot{B}$ の大きさが 実際のボールに与えられる自転回転数（スピン）を，ベ クトル $\dot{B}$ と直交する方向がボールの回転軸を示すことに なる. たとえば, 先の $\dot{B}$ の場合, ボールに対して図6(c)の 状態となり, これは球種がカーブとなる. 同様に, シュ 一ト，ドロップなども同図(b)に示す範囲として表現する ことができる. なお， $0<B_{Y}<0.5$ の範用では，ボールの回 転は順回転（フォロースピン），一方 $0.5<B_{Y}<1.0$ の範囲 では，逆回転 (バックスピン)， $B_{X}=B_{Y}=0.5$ では，無回転 ボールとなる.一般に, 変化球は回転軸とスピンで決定 できるため, 2 つの球種パラメータ $B_{X}, B_{Y}$ で, あらゆる 変化球を表現することか可能であると考えられる.なお, この手法の妥当性については, 次章の基本性能試験で検 討する.

\section{6. 知的ピッチングマシンの性能評価}

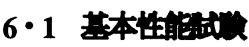

本ピッチングマシンで 3 個のローラの回転数 $N_{1}, N_{2}$ $N_{3}$ および角度 $\theta, \phi$ 変化させることで, どのようなボ 一ルが投げられるかをまず調べた. 実験用のボールは現 在プロ野球に使用されている硬式ボールと同じボールを 用いた. 実験は, 図 7に示すようなピッチングマシンと 距離 $14 \mathrm{~m}$ をおいて幅 $0.75 \mathrm{~m}$ ，高さ $1.25 \mathrm{~m}$ の的を設置し，
室内で行った. また 3 個のローラの回転数とマシンの上 下角, 左右角を任意に選定して投球を行った. 図 8 はそ の一例で 115 パターンを投球したとき, 的に当たったコ 一スの位置座標の結果を示す. すべてのデー夕は 1 パ夕 ーンの投球に対して 3 球投球を行いその平均值を用いて いる. これより, ほとんどすべての領域にボールを投球 できることがわかる. 次に, 図 9は3つのローラの回転 数の総和 $\left(N_{1}+N_{2}+N_{3}\right)$ とボールの速度 $V$ との関係を示した ものである.これより, 両者にはほぼ線形性があること, また本マシンでは球速 70〜 $160 \mathrm{kmh}$ の範囲のボールが投 球可能であることなどがわかる. また, 高速度ビデオ力 メラを用いて各球種におけるボールの回転の様子を撮影

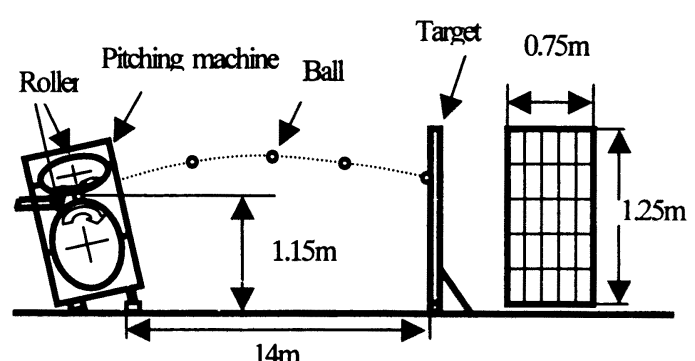

Fig.7 Experiment conditions

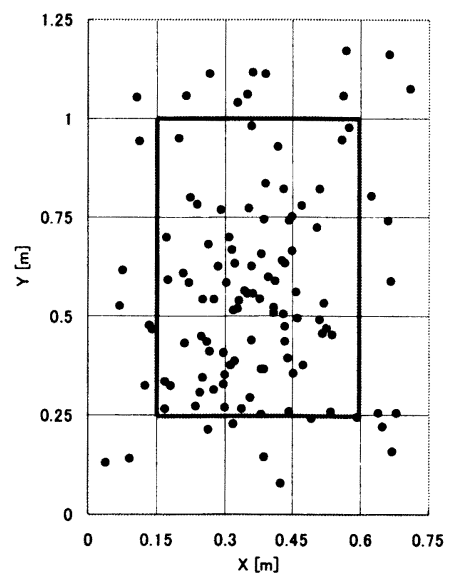

Fig.8 Example of pitching ball

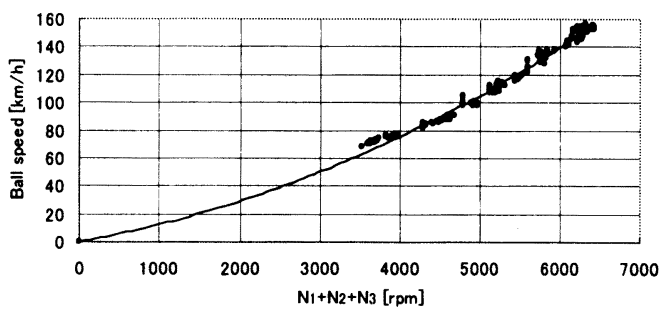

Fig.9 Relation between ball speed and revolution number of roller 
した. 図 10 はその一例で, $N_{1}=2100 \mathrm{pm}, N_{2}=N_{3}=1500 \mathrm{pm}$, $\theta=\phi=0^{\circ} \quad\left(B_{X}=0.5, B_{Y}=0.6\right)$ の条件，つまり球種がスト レートのときのボールの回転の様子を示したものである. これより, 本マシンで投球したボールは実際のピッチャ 一の投球と同様, きれいなバックスピン回転をしている. 同様に図 11 は $\left(B_{X}=0.4, B_{Y}=0.42\right)$ の条件, カーブの回転 の様子を示したものである.これを見るとボールの回転 軸は鉛直方向からやや傾いた方向で，その回転はフォロ ースピン回転をしており, 先の図6(c) の回転軸方向, ス ピンとほぼ一致していることがわかる. また, 図には示 していないが, ドロップ, シュート等についてもビデオ 撮影を行いその回転の様子を確認している. これらのこ とから, 種々の変化球を前章の球種パラメータ $B_{X}, B_{Y}$ の 2つで表現する本手法が十分妥当であるといえる.

\section{$6 \cdot 2$ 総合性能霖価}

前節の実験データを教師データとして $\mathrm{NN}$ をバック プロパゲーション法により学習させた. なお, $N_{1} \sim N_{3}$,

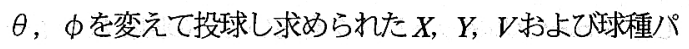
ラメータ $B_{X} ， B_{Y}$ (ただし，これらは 5 章で述べた $N_{1} \sim N_{3}$ から求めたものである) の組を学習データとして NNを 構築している.図12に学習過程の一例を示す.これより, 教師データ数にかかわらず，学習回数とともに誤差が減 少していることがわかる.

学習済みのNNを用いて実際の投球試験を行った. 図 8に示した 115個の投球データを教師データとして学習さ せたネットワークで希望球種の投球試験を行った結果の 一例を図 13 に示す. つまりあらかじめ希望したコース, 5 つの速度 $(70,90,110,130,150 \mathrm{kmh})$ および 4 つの 球種（ストレート, ドロップ, カーブ, シュート) を決

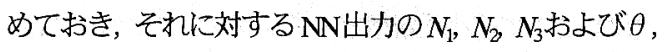

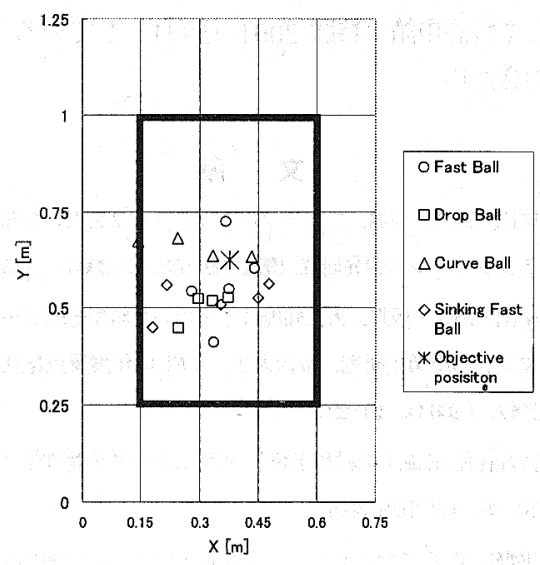

(a) Case by the variable ball фを用いて投球した結果である. 図中の*印が希望した ボールの位置 (的の真中) を示し, 図 13(a)では投球試験

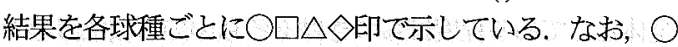
はストレート, ロはドロップ, வはカーブ, ১はシュー トをそれぞれ示している. 一方図 13 (0)では同様の実験結

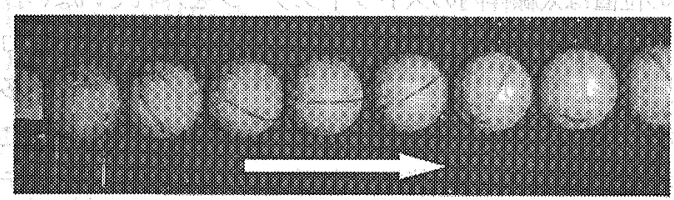

Fig.10 Behavior of the spin of fast ball using the high speed camera ( $2 \mathrm{~ms} /$ frame)

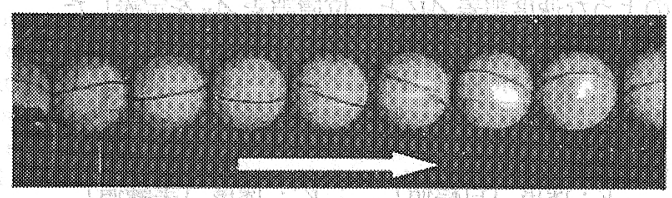

Fig.11 Behavior of the spin of curve ball using the high speed camera ( $2 \mathrm{~ms} /$ frame)

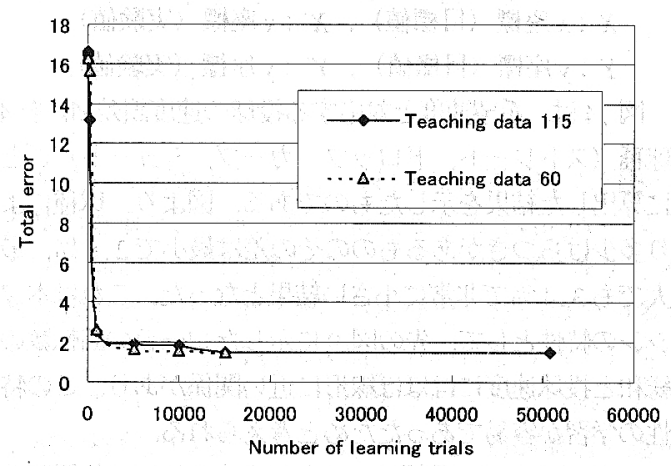

Fig.12 Error convergence situation

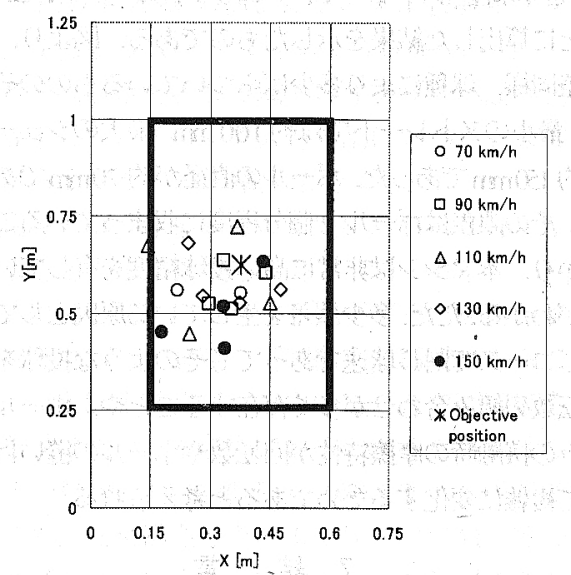

(b) Case by the speeds ball

Fig.13 Experimental results of ball using NN control 
果を各速度をパラメータにして示している. これらの結 果より, 速度や球種では明確な相関関係はみられないが, 全体としてある程度ばらつきはあるものの目標位置近傍 に分布している. また, プロ級である速度 $150 \mathrm{kmh}$ のボー ルをはじめ, いずれの速度や球種のボールにおいてもそ の位置は太線枠内のストライクゾーンを外れていない良 い結果であった.これより, 開発した本マシンは, プロ 野球をも含む現状の野球で想定される広範囲の速度, 多 様な球種のボールを瞬時にかつ, ほぼ希望したコースに 投げ分けることが可能で, 市販のマシンに比べ高いポテ ンシャルを有しているといえよう.

なお以上述べた結果をより定量的に評価するため, 次 のような速度誤差 $\Delta V$ と, 位置誤差 $\Delta r$ を定義した.

$$
\Delta V=\left|\frac{V^{\prime}-V}{V}\right| \times 100
$$

$V:$ 速度（目標值）， $V^{\prime}:$ 速度（実験值）

$$
\Delta r=\sqrt{\left(X^{\prime}-X\right)^{2}+\left(Y^{\prime}-Y\right)^{2}}
$$

$X: x$ 座標 (目標値) $, X^{\prime}: x$ 座標（実験值）

$$
Y: y \text { 座標 (目標值) }, Y^{\prime}: y \text { 座標（実験值） }
$$

図 14 は，希望速度と対応する投球の速度誤差 $\Delta V$ を 4 球種（ストレート, ドロップ, カーブ, シュート) ごと に算出した結果を示したものである. 図より, 球種によ り多少ばらつきがあるもののその差は最小で $2.6 \%$, 最 大でも $3.4 \%$ で非常に小さい結果となった. これは本マ シンの特性として, 先の図 9 に示したローラの回転数の 総和と投球速度にはほぼ線形に近い関係があり，この特 性の学習か溶易であったためと考えられる.

一方, 図 15 は, 希望コ一スと対応する投球の位置誤差 $\Delta r$ を球種 (ストレート, ドロップ, カーブ, シュート) ごとに算出した結果を示したものである. 図より, 速度 誤差同様, 球種により多少ばらついているもののその差 は, 最小のストレートでは約 $100 \mathrm{~mm}$, 最大のシュートで も約 $150 \mathrm{~mm}$ であった. ボールの直径が約 $70 \mathrm{~mm}$ であるの で，その䛣差はボール 2個分程度に収まっていることが わかり, 本マシンは非常に高い投球精度を有しているこ とがわかる.ただ, 多少誤差を生じている原因としては, 同じコースで同じ球速であってもそのような投球をする 回転数の組み合わせが多く存在することや, ボールとロ 一ラの接触時の摩擦特性が回転数やボールの縫い目によ って複雑に変化するためであると考えられる.

\section{7. 結 言}

本研究では3ローラ式の新型ピッチングマシンを開発

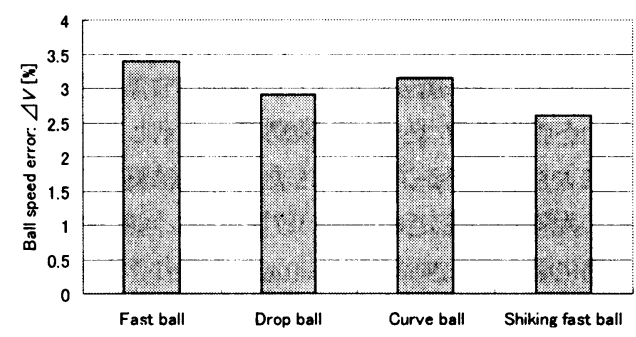

Fig.14 Relation between ball speed emor and variable ball

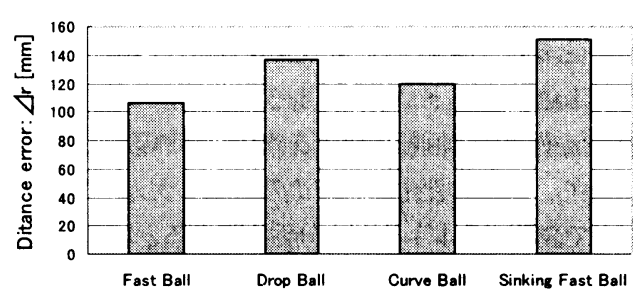

Fig.15 Relation between distance error and variable ball

し, ニューラルネットワークを用いてその回転数やボー ルの発射角を決定することにより希望したコースに, 希 望した速度と球種（変化球）のボールを投球させること を試みた. その結果, 多様な球種で球速が 70〜 $160 \mathrm{kmh}$ の広範囲で投球可能であり，またその投球精度は，速度 と球種についてはほぼ完全に, またコースについても, ボール 2 個程度の精度で予測が行えた.これは，現状の ピッチッグマシンを遥かに凌ぐ十分な精度であり, 非常 に実用性の高い新型のピッチングマシンであるといえる.

最後に, 本研究にあたり, 当時本学 4 年生であった高 桑啓介君，川村匠君にはマシンの製作や実験の際に多大 なるご協力を頂いた，ここで謝意を表したい．

なお,ここで述べた新型ピッチングマシンについては, その構造と制御方法を含めてすでに科学技術振興事業団 を通して特許申請（特願 2001-45941）していること述 べておきたい.

\section{文 献}

（1）尾田・酒井・羽場，ニューラルネットワークを用いた知的ピッ チングマシンの開発研究, 機論, 69-678, C (2003)， 135-140.

（2）尾田・酒井・坂野, 人工知能技術を用いた新型知的ピッチング マシンの事業化研究, 金沢大学 平成 14 年度重点化経費研究 抄録, (2003), 19-22.

（3）RobertKAdair, ( 中村和幸訳 ), ベースボールの物理学, (1996), 10-36, 紀伊国屋書店.

（4）平野広美, Cでつくるニューラルネットワーク,(1991), 15-46, パーソナルメティア. 